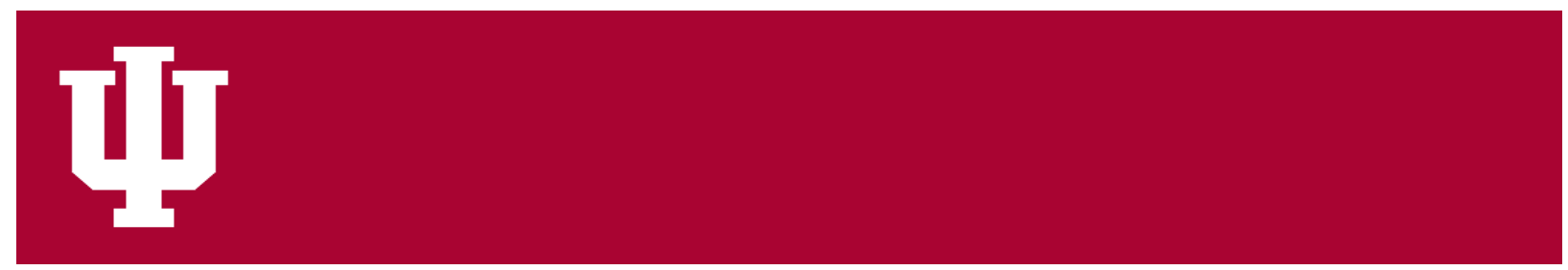

IUScholarWorks at Indiana University South Bend

\title{
Corporatism Reconsidered: Howard J. Wiarda's Legacy
}

Chen, Linda

To cite this article: Chen, Linda. "Corporatism Reconsidered: Howard J. Wiarda's Legacy." Polity, vol. 50, no. 4, The University of Chicago Press, Sept. 2018, pp. 601-11.journals.uchicago.edu (Atypon), doi:10.1086/699630.

This document has been made available through IUScholarWorks repository, a service of the Indiana University Libraries. Copyrights on documents in IUScholarWorks are held by their respective rights holder(s). Contact iusw@indiana.edu for more information. 


\title{
Corporatism Reconsidered: Howard J. Wiarda's Legacy
}

\author{
Linda Chen, Indiana University, South Bend
}

This article takes stock of Howard J. Wiarda's contributions to the concept of corporatism. In 1973, Wiarda published a seminal article in World Politics, titled "Toward a Framework for the Study of Political Change in the Iberic-Latin Tradition: The Corporative Model," that laid out his theory of corporatism in the Latin American context. In it, he argued for a theory of corporatism that focused on the intellectual and cultural roots of the concept. He argued that corporatism provided a more historically grounded framework for understanding Latin American political change than modernization theory. This essay asks: In what ways did Wiarda lay claim to a distinctive Latin American variety of corporatism? What implications did this have for an understanding of Latin American politics? Finally, how have his claims about corporatism held up over time?

Keywords: corporatism, neo-corporatism, Latin America, Howard J. Wiarda, political culture

\section{Wiarda and His Latin American Context}

$\mathrm{I}_{\mathrm{v}}^{\mathrm{n}}$ n the 1960s, as Howard J. Wiarda finished up his graduate studies at the University of Florida, Latin America was in turmoil. The Cuban Revolution jolted the United States to the realization that communism had gained a foothold in the Americas. Nation after Latin American nation became militarized. Other nations saw the reins of government remain tightly controlled by authoritarian strong men of the caudillo variety or by family dynasties. These developments begged for analysis, one that modernization theory could not provide. Wiarda and others studying Latin America at the time viewed corporatism as a useful framework for understanding the rise of authoritarianism in Latin American politics.

I would like to thank Esther Jordan and Tony Spanakos for their support and patience throughout this project. I would also like to thank Neovi Karakatsanis for reading multiple drafts of this article.

Published online September 20, 2018. http://dx.doi.org/10.1086/699630

Polity, volume 50, number 4 (October 2018), pp. 601-611. 0032-3497/2018/5004-0007\$10.00.

(C) 2018 Northeastern Political Science Association. All rights reserved. 
Wiarda's working definition of corporatism entailed a "system of social and political organization in which major societal and interest groups are integrated into the governmental system, often on a monopolistic basis under state guidance, tutelage and control, to achieve coordinated national development." In corporatist political systems, power is concentrated in the hands of the state, which mediates relations among major social groups by recognizing certain organizations as the legitimate and sole representative of their members' interests. These officially recognized interest groups, organized along functional lines into corporatist associations, are then able to enjoy advantages offered by the state, which include access to resources and the ability to make demands of the state through routine channels. In return, the state expects to exercise authority and control over the kinds of demands made by the corporatist associations, and even a degree of control over their internal affairs. The overriding purpose of this corporatist framework is to allow the state to manage change and to maintain order and harmony among its corporatist entities. It preserves and even expands the power and interests of state-recognized organizations within a power structure where they enjoy certain rights and privileges not granted to others. ${ }^{2}$

Wiarda argued that corporatism was the expression of a culture inherently authoritarian, hierarchical, undemocratic, and based on natural law. Corporatism offered an overarching philosophy and ideology for the distinctiveness of Latin American development. ${ }^{3}$ Wiarda's unique contribution to the debates concerning corporatism was to ask and answer the question of why corporatism in Latin America existed in the first place.

Wiarda's beliefs about corporatism led him to trace the concept's roots to sixteenth-century Spanish and Portuguese Roman Catholicism. The Iberian expression of Roman Catholicism emphasized the importance of hierarchy and authoritarian power relations. Individual will was subordinated to the will of God and therefore to his representative on earth, the king. Individual liberty was only recognized within the context of functional group identity. On the secular side,

1. Howard J. Wiarda, "The Political Sociology of a Concept: Corporatism and the 'Distinct Tradition," The Americas 66 (July 2009): 81-106, at 93.

2. Howard J. Wiarda, "Toward a Framework for the Study of Political Change in the IbericLatin Tradition: The Corporative Model," World Politics 25 (January 1973): 206-35; and his "Corporatism and Development in the Iberic-Latin World: Persistent Strains and New Variations," Review of Politics 36 (1974): 3-33.

3. David Collier, "Trajectory of a Concept: 'Corporatism' in the Study of Latin America," in Latin America in Comparative Perspective: New Approaches to Methods and Analysis, ed. Peter Smith (Boulder, Colo.: Westview, 1995), 135-62. 
Wiarda pointed to the practice of fueros, in which the king granted groups sets of rights and privileges. In return for these rights and privileges, these groups ensured that their members worked within the parameters set by the king and recognized the king's authority. ${ }^{4}$

According to Wiarda, state-society relations in medieval Spain and Portugal were organized in a pyramidal shape. The king sat at the top of the pyramid, with corporatist groups arrayed below him and everyone else below them. Power and privilege emanated from the king to the corporatist groups below. The corporatist groups were meant to be non-competitive, but in reality, much jockeying for power and influence took place within and among them. Wiarda emphasized the hierarchical and authoritarian nature of these societies, ones where power was concentrated among a small elite group of interests and where individualism was subordinated to group identity. Groups not recognized by the state were suppressed. Notions of individual liberty and rights were alien to this philosophy. These were inherently conservative societies that sought to preserve a political order that was segmented and that protected the status quo. ${ }^{5}$

Wiarda argued that medieval Catholic Spain and Portugal exported corporatism to the Americas. The emphasis on centralized authority, hierarchical relationships, group rights over individual rights, and obedience to authority were all baked into the cultural ethos of Latin America and accounted for its distinctiveness. This was in direct contrast to the British colonies, where the ideas of liberalism, with its emphasis on Protestantism, individual rights, diffuse authority, and equality, would eventually take root. ${ }^{6}$

For Wiarda, colonial Latin America embodied the same corporatist patterns as Spain and Portugal. An appointed viceroy represented the king's interests in colonial Latin America. Along with the interests of the Catholic Church, corporatist groups included a landed oligarchy, conquistadors, and later the military. The independence wars of the nineteenth century did not significantly alter the pattern of power relations, even as new philosophies such as positivism and liberalism competed with corporatism for political dominance. Corporatist power relations continued to prevail. Men on horseback, or caudillos, ruled with their own armies and often used force to maintain the corporatist status quo. In Latin American

4. Wiarda, "Corporatism and Development," 13-24 (see note 2 above); Howard J. Wiarda, The Soul of Latin America: The Cultural and Political Tradition (New Haven, Conn.: Yale University Press, 2001), 59-83.

5. Wiarda, "Toward a Framework," 206-35 (see note 2 above); "Corporatism and Development," 13-24 (see note 2 above); and The Soul of Latin America, 246-80 (see previous note).

6. Wiarda, "Toward a Framework," 208-17 (see note 2 above). 
society, elite corporate interests dominated the economy and politics. The state continued to exercise a great deal of power over all aspects of society, and the growth of military establishments was a natural development for maintaining corporatist political order. ${ }^{7}$

Wiarda traced the persistence of corporatism into the twentieth century. In response to economic forces, Latin American societies, especially in the Southern Cone, witnessed the growth of commercial interests, as well as waves of workingclass immigrants from Europe. The traditional corporatist power structures faced pressure from these groups for representation, and corporatist regimes co-opted them into the corporatist fold as a means of staving off more radical change. For example, while labor union federations were given the right to represent their member unions' interests, the state exercised the prerogative to influence and control the unions' demands, leadership, and subsidies. Political change under corporatism in the 1940s and 1950s was a process that continued to emphasize functional group identity and the continued centralization of power by the state. ${ }^{8}$

Military authoritarianism in Latin America resurged in the 1960s and 1970s, and Wiarda viewed it as a natural outgrowth of the persistence of corporatism. Believing as he did in the cultural underpinnings of corporatism, which he obsessively contrasted to U.S.-style liberalism, Wiarda argued that military authoritarianism resulted from the cultural norms of Latin American society, with its roots in Iberian Catholic traditions. The military variety of corporatism, contrary to the corporatist policies of the 1940s and 1950s, relied on the use of force to maintain social order. Instead of coopting groups into the corporatist fold, military corporatism resorted to exclusionary policies, especially against labor unions Wiarda viewed the militarization of Latin American society in the 1960s and 1970s as reinforcing its corporatist underpinnings. ${ }^{9}$

\section{Wiarda and his Critics}

From their inception, Wiarda's claims were challenged by his contemporaries. Philippe Schmitter, who is arguably the foremost authority on corporatism and whose definition of corporatism is the standard in the field, argued in "Still the

7. Ibid., 206-35; Howard J. Wiarda, Latin American Politics (New York: Wadsworth, 1995), ch. 1 .

8. Wiarda, "Corporatism and Development," 24-33 (see note 2 above); Wiarda, The Soul of Latin America, 257-70 (see note 4 above).

9. Wiarda, "Corporatism and Development," 31-33 (see note 2 above); Wiarda, The Soul of Latin America, 271-80 (see note 4 above). 
Century of Corporatism?" that Wiarda's emphasis on the cultural roots of corporatism veered too closely to already discredited ideas about national character. ${ }^{10} \mathrm{He}$ summarily rejected the overriding premise that corporatism was rooted in Roman Catholic doctrine and saw little utility in viewing corporatism as an ideological construct. He further went on to give examples of where corporatism existed in non-Iberian parts of the world and offered non-Iberian examples of corporatist ideologies. In a particularly devastating footnote, Schmitter argued that too many "Anglo-Saxon" students of Latin America engaged in "impressionistic and circular" reasoning when arguing that the assumed differences between Latin America and North America were due to their different religious heritages. ${ }^{11}$ To Schmitter, corporatism was characterized by a system of interest representation linking the organized interests of civil society to the interests of the state, as in his widely accepted definition:

Corporatism can be defined as a system of interest representation in which the constituent units are organized into a limited number of singular, compulsory, noncompetitive, hierarchically ordered and functionally differentiated categories, recognized or licensed (if not created) by the state and granted a deliberate representational monopoly within their respective categories in exchange for observing certain controls on their selection of leaders and articulation of demands and support. ${ }^{12}$

Absent from Schmitter's definition are any claims to historical or cultural determinism. He also argued that his definition made no claims or assumptions that corporatist arrangements are the only arrangements that prevail in any given polity. Instead, he maintained that corporatist interest group arrangements could and do exist side by side with other forms of interest group representation in a given polity. In short, Schmitter was squarely focused on the institutional practices and structures of interest representation, of which corporatism offered a model distinct from that of pluralism.

Guillermo O'Donnell, writing at about the same time, also took issue with Wiarda's historico-cultural explanation of corporatism. While not a scholar of corporatism, O'Donnell viewed corporatist structures and practices as integral to his then developing views on the emergence of authoritarianism in Latin America.

10. Philippe Schmitter, "Still the Century of Corporatism?" Review of Politics 36 (1974): 85131.

11. Ibid., 90 .

12. Ibid., 93-94. 
Like Schmitter, O’Donnell rejected the culturally deterministic claims of Wiarda's corporatism. To O'Donnell, the corporatist structures and practices in existence at the time in Latin America were a distinctive phenomenon that evolved out of the specific pattern of development of Latin American society and politics, which was characterized by delayed dependent development and the legacy of populism. O'Donnell saw corporatism not as a static phenomenon but as one that varies over time and according to national circumstance. Corporatist practices were conscious decisions made by elite groups who sought to preserve their power in the face of a politicized populace within the context of the demands of economic globalization. O'Donnell was particularly critical of Wiarda's overreliance on analyzing ideological and legalistic forms of corporatism. O'Donnell believed this approach hid the fact that corporatist theory was usually not borne out in actual practice. For example, although corporatist ideology focused on promoting social harmony, this was rarely a reality; rather, corporatist structures and practices often masked the segmented nature of interest groups that competed against each other for resources. It also masked the power relations that inherently subordinated the interests of some groups to others. According to O'Donnell, rather than achieving social harmony, corporatism ultimately meant reinforcing unequal power relations in a society. ${ }^{13}$

While Schmitter and O'Donnell rejected Wiarda's approach to corporatism, Al Stepan offered a bridge between the two contending perspectives on the concept. Stepan separated out the ideological and cultural dimensions from the policy and practice of corporatism. Stepan agreed with Schmitter and O'Donnell that corporatism in Latin America was a set of policies and practices that were put in place through the conscious decisions of elite groups who saw their interests threatened by a politicized populace. However, he also saw that it was useful and necessary to analyze the ideological justifications of such actions. Stepan's analysis of Latin American politics was encompassed in the idea of organic-statism, in which he delineated the justifications that the state used to impose corporatist practices and structures. In this respect, he refined Wiarda's emphasis on political culture without sliding into cultural determinism. ${ }^{14}$

Almost twenty years after the above arguments were made, David Collier took stock of the trajectory of the concept of corporatism in the Latin American context. Collier's analysis showed that the emphasis on corporatism as a way of analyzing

13. Guillermo O'Donnell, "Corporatism and the Question of the State," in Authoritarianism and Corporatism in Latin America, ed. James Malloy (Boulder, Colo.: Westview, 1977), 47-88.

14. Al Stepan, The State and Society: Peru in Comparative Perspective (Princeton, N.J.: Princeton University Press, 1978), 4-45. 
interest groups and their relationship to the state had dominated the literature since the 1970s. Studies in the 1980s and 1990s sought to draw out the ways and extent that corporatist practices took hold among differing groups in society. Analyses of the heterogeneity of corporatist practices across time and countries, as well as differences in corporatist practices among groups within a country, contributed to the refinement of corporatism as a concept. While the majority of studies on corporatism followed the ideas of Schmitter and his focus on structure and practice, Collier argued that Wiarda's emphasis on the political philosophy or tradition of corporatism should not be dismissed out of hand. While Collier certainly did not endorse Wiarda's interpretation of Latin American corporatism, he did view Wiarda's attention to the question of political culture as an important one deserving of further research. ${ }^{15}$

Ultimately, corporatism waned in importance as Latin America began transitioning from military rule toward civilian democratic practices. The emergence of new ways of practicing democratic politics and the reemergence of political parties meant that corporatist practices waned in scope and importance. As a result, Schmitter, O'Donnell, Stepan, Collier, and others turned their analytical attention to the emerging wave of democratization, with O'Donnell and Schmitter's edited series (with Laurence Whitehead) on Transitions from Authoritarian Rule setting the intellectual foundations for research on Latin American politics in the late 1980s and beyond. ${ }^{16}$ By that time, Wiarda had turned his attention to foreign policy issues, but he remained skeptical of the staying power of these transitions. While most scholars of Latin American politics in the late 1980s were cautious in their analyses of the democratic transitions, Wiarda remained particularly pessimistic about democracy's staying power. ${ }^{17}$

\section{Corporatism after Authoritarianism}

Writing thirty-five years after the publication of the World Politics article, Wiarda's ideas about corporatism became more flexible. His travels to various European countries led him to analyze corporatist practices in non-Catholic countries, such as Austria, Greece, and Germany. Labeled neo-corporatism, in these countries Wiarda saw manifestations of a more inclusionary social type of corporatism that was

15. David Collier, "Trajectory of a Concept," 135-62 (see note 3 above).

16. Guillermo O'Donnell, Philippe Schmitter, and Lawrence Whitehead, Transitions from Authoritarian Rule: Latin America (Baltimore, Md.: Johns Hopkins University Press, 1986)

17. Wiarda, "Soul of Latin America," ch. 11 (see note 4 above). 
compatible with liberal democratic norms. ${ }^{18}$ Markus Crepaz traces the evolution of Wiarda's contributions to this discussion in the next essay of this symposium. ${ }^{19}$

As mentioned, Wiarda was skeptical that the transitions to democracy of the 1980s would endure. He was very critical of the problems that democratization was engendering and often used the adjectives "chaotic," "inchoate," and "tenuous" to characterize the processes of democratization taking place continent-wide. He was convinced that despite this trend, corporatist practices would reassert themselves. His edited volume, Authoritarianism and Corporatism in Latin America-Revisited (2004), focused on how corporatist structures and practices continue to persist even in democratic settings. ${ }^{20}$ In this volume, Wiarda stated that while corporatism was no longer the dominant paradigm in national politics, state-society relations in contemporary Latin America contained a hodgepodge of differing arrangements, with corporatist practices still existing in areas such as state-labor relations, for example. $^{21}$

Argentina offers an example of how corporatism has adapted to changing political conditions, especially in state-labor relations. Modern corporatism in Argentina took the form of state-directed, top-down control under the first administration of Juan Perón in the 1940s. Perón oversaw an inclusionary state corporatism characterized by a labor union confederation that exercised influence over economic decision making. The decades after the overthrow of Perón were characterized by attempts to depoliticize and demobilize labor union activism. From the 1940s to the 1970s, corporatism in Argentina moved on a continuum from inclusionary to exclusionary state-controlled practices. Corporatist structures persisted as successive military regimes promoted exclusionary policies to control a largely Peronist-dominated labor movement. ${ }^{22}$

The democratization of Argentine politics created new challenges to traditional corporatist arrangements. The democratic regime of Raúl Alfonsín in the 1980s

18. Wiarda, "The Political Sociology of a Concept," 81-106 (see note 1 above).

19. Markus M. L. Crepaz, "Of Paradigms Won and Lost: The Neo-Corporatist World According to Howard J. Wiarda," Polity 50 (2018): 612-21.

20. Howard J. Wiarda, ed., Authoritarianism and Corporatism in Latin America Revisited (Gainesville: University of Florida Press, 2004)

21. Howard J. Wiarda, "Introduction: Whatever Happened to Corporatism and Authoritarianism in Latin America?" 1-28, and "Conclusion: New Directions in Research, Theory, and Policy," 282-305, in Authoritarianism and Corporatism in Latin America Revisited (see previous note).

22. Linda Chen, "Corporatism Under Attack? Authoritarianism, Democracy, and Labor in Contemporary Argentina," in Authoritarianism and Corporatism Revisited, ed. Wiarda, 197217 (see note 20 above). 
saw attempts to break down corporatist practices by forcing labor unions to hold open and free elections. The political goal was to decrease the influence of Peronism within the labor movement and to decrease the control of labor unions over subsidies and union dues. This was mildly effective, but Argentine labor leaders were able to maintain their power via legislation supported by the Peronist Party. The greatest threat to corporatist arrangements came from Alfonsín's successor, Carlos Menem, in the 1990s. Menem represented a new generation of Peronists who sought to align with neoliberal economic policies. This meant the dismantling of corporatist arrangements and the deindustrialization of the labor force, as well as efforts to respond to global capital by privatizing state-owned industries and diminishing the bargaining power of labor unions. ${ }^{23}$

These policies were seen by many analysts as destroying any vestiges of corporatism in Argentina. The state was no longer the dominant player in economic policy making, and previously strong labor unions were crippled by globalization. However, in Argentina, corporatist practices have recently been revived. The collapse of neoliberalism in the early twentieth century witnessed the return of an activist state role in economic policy making coupled with a resurgent labor union movement. The post-neoliberal era of Néstor Kirchner (2003-07) emphasized redistributive economic policies that favored labor's interests. Labor unions found themselves in a position of strength to negotiate with a government that was open to incorporating them into economic policy making. ${ }^{24}$

Sebastian Etchemendy and Ruth Berins Collier characterize this development as "segmented neo-corporatism." Like its European counterpart of neo-corporatism, segmented neo-corporatism indicates a greater autonomy for the labor movement vis-à-vis the state. It differs from European neo-corporatism in that the new corporatist arrangements cover only a small group of workers-in this case, the better paid unions. It also differs from European neo-corporatism in that its relationship with the state is more narrowly focused on wages and labor laws, without the corresponding inclusion of social welfare policy as a moderating influence on wage demands. ${ }^{25}$

The case of Argentina demonstrates that corporatism can and does adapt to changing economic and political circumstances. Wiarda in his later work alluded

23. Ibid., 197-217.

24. Sebastian Etchemendy and Ruth Berins Collier, "Down but Not Out: Union Resurgence and Segmented Neo-Corporatism in Argentina (2003-2007)," Politics and Society 35 (2007): 363-401.

25. Ibid. 
to this adaptability and indicated that corporatism could still be a fruitful area for further research. However, despite acknowledging the existence of corporatist structures in liberal democracies, Wiarda remained skeptical about the long-term prospects for democracy in Latin America. ${ }^{26}$ In his mind, Latin American political culture was inherently trapped in its medieval past. He would use the phrase "living museum," coined by historian Charles Anderson, to characterize the conservatism of the region. Corporatism and its underlying rationale was inherently a reflection of Latin American political culture. ${ }^{27}$ In that respect, while corporatist arrangements could exist side by side with liberal democratic norms, it was a tenuous relationship. Wiarda insisted on his view that Latin American corporatism was at heart incompatible with liberal democratic norms. ${ }^{28}$

To Wiarda, the importance of political culture could not be overstated. While he criticized cultural relativism, he nevertheless continued to emphasize that "corporatism was a way of looking at (a verstehen approach) and understanding Latin America and Iberia on their own terms, in their own language and cultural conditions." ${ }^{29}$ The challenge, though, was who and what would define Latin America. Critics of Wiarda's political culture approach point out that he focused too narrowly on certain aspects of culture and political history. His research in the field emphasized elite sensibilities and perspectives, and therefore lacked a full understanding of how ordinary Latin Americans viewed cultural norms. Critics see the emergence of new actors in Latin American society such as women's groups, peasant organizations, urban workers organizations, squatter movements, and indigenous people's movements as illustrating the need to analyze how these groups understand and live their culture. ${ }^{30}$ The dichotomy that Wiarda saw between corporatist and liberal democratic norms is a limitation to his political culture-driven understanding of Latin America. By always comparing corporatism to liberal democracy, Wiarda ignored the variety of institutional arrangements that fall under liberal democracy. By so doing, he failed to appreciate that corporatism, even the Latin American kind, could coexist and even thrive under liberal democratic conditions.

26. Wiarda, "The Political Sociology of a Concept," 102-06 (see note 1 above).

27. Wiarda, "Soul of Latin America," 283 (see note 4 above).

28. Wiarda, "The Political Sociology of a Concept," 102-06 (see note 1 above).

29. Ibid., 94 .

30. Carlos Loazada, "Does Culture Matter? (Review)," Commonweal, November 23, 2001, 24-25; Thomas Skidmore, "The Soul of Latin America (Review)," Lournal of Interdisciplinary History 33 (2002): 152-53. 


\section{Conclusion}

Wiarda, one of the original architects of corporatist theory, was motivated by the inadequacies of modernization paradigms to explain Latin American political development. Corporatism offered a framework for understanding and explaining the structures and practices that military regimes adopted for organizing group interests that contrasted with the dominant paradigm of pluralism. Unlike his contemporaries, Wiarda sought to illuminate the philosophical and cultural underpinnings of corporatism. Forty-five years after the publication of Wiarda's World Politics article, Schmitter and others have demonstrated that corporatism is neither unique to Latin America nor a phenomenon that exists primarily in Catholic nations. However, it is also the case that corporatist practices persist in Latin America, even if to a limited extent. Even as Wiarda failed to appreciate how corporatism could evolve over time, he challenged us to rethink how we conceptualize development and politics. This remains his lasting legacy to political science.

Linda Chen is Interim Executive Vice Chancellor for Academic Affairs and Professor of Political Science at Indiana University, South Bend. She studied with Howard J. Wiarda at the University of Massachusetts, Amherst, where she obtained her Ph.D. in 1988. Her political science research has focused on Argentina and democratization. She can be reached at lchen@iusb.edu. 